\title{
Suppression of the secondary FSH surge with bovine follicular fluid is associated with delayed ovarian follicular development in heifers*
}

\author{
A. M. Turzillo and J. E. Fortune \\ Department and Section of Physiology, New York State College of Veterinary Medicine, \\ Cornell University, Ithaca, New York 14853, USA
}

\begin{abstract}
Summary. Holstein heifers were given 5 injections (twice/day) of $10 \mathrm{ml}$ charcoalextracted bovine follicular fluid ( $\mathrm{bFF} ; \mathrm{N}=6$ ) or $10 \mathrm{ml}$ saline $(\mathrm{N}=5$ ) beginning $12 \mathrm{~h}$ after the onset of oestrus. Blood samples were collected for determination of plasma concentrations of FSH, LH, progesterone and oestradiol-17 $\beta$. Treatment with bFF suppressed the secondary FSH surge $(P<0 \cdot 01)$. Cessation of bFF injections was followed by a rebound period during which FSH was elevated compared with controls $(P<0.01)$. Daily ultrasonographic examinations revealed that follicular growth occurred in waves, with 4 of 5 control heifers exhibiting 3 waves and the other 2 waves. In contrast, 5 of 6 bFF-treated animals exhibited 2 waves and the other 3 waves. Appearance of follicles in the first wave was delayed in bFF-treated heifers (Day $3 \cdot 3 \pm 0 \cdot 3$ compared with Day $1 \cdot 4 \pm 0 \cdot 2 ; P<0.0001)$ and appearance of the dominant follicle of the first wave was delayed (Day $4.5 \pm 0.3$ compared with Day $1.8 \pm 0.2$; $P<0.0001)$. Follicles in the second wave appeared later in animals treated with bFF (Day 12.7 \pm 0.4 compared with Day 10.4 $\pm 0.6 ; P<0.01$ ), and the dominant follicle of this wave also appeared later (Day 13.0 \pm 0.5 compared with Day 10.6 \pm 0.5 ; $P<0.01)$. Oestradiol-17 $\beta$ increased during the early luteal phase, but this increase occurred later in heifers treated with bFF (peak concentrations on Day $6 \cdot 3 \pm 0.6$ compared with Day $4 \cdot 2 \pm 0 \cdot 2 ; P<0.05$ ). $\mathrm{LH}$, progesterone and cycle length were not affected by bFF. Delayed follicular growth associated with suppression of FSH suggests that the secondary FSH surge is important in the initiation of follicular development early in the bovine oestrous cycle, and thus may play a role in the regulation of ovarian follicular dynamics.
\end{abstract}

Keywords: ovary; follicles; FSH; cattle; follicular fluid

\section{Introduction}

The pituitary gonadotrophins LH and FSH are both necessary for ovarian follicular development (Greep et al., 1942), but the relative roles of these hormones in stimulating folliculogenesis are not fully understood. During the bovine oestrous cycle, preovulatory surges of LH and FSH occur simultaneously (Dobson, 1978; Walters \& Schallenberger, 1984) and basal plasma concentrations are parallel throughout much of the luteal phase (Rahe et al., 1980; Schallenberger et al., 1985). However, circulating levels of LH and FSH are clearly divergent during two periods of the oestrous cycle in cattle, suggesting that these times may be critical for ovarian follicular stimulation by appropriate concentrations of each gonadotrophin. Following luteolysis, increases in basal LH and

\footnotetext{
*Reprint requests to: Dr J. E. Fortune, 823 Veterinary Research Tower, Cornell University, Ithaca, New York 14853,
} USA. 
LH pulse frequency (Rahe et al., 1980) are accompanied by decreased FSH concentrations (Butler et al., 1983; Schallenberger et al., 1984). Patterns of LH and FSH also differ early in the luteal phase, when there is a second increase in plasma FSH but there is no concomitant rise in $\mathrm{LH}$ (Dobson, 1978; Roche \& Ireland, 1981; Quirk \& Fortune, 1986). There is evidence that a similar secondary 'surge' in FSH is important for development of follicles for the next ovulatory cycle in rats (Grady et al., 1982). The magnitude of the secondary FSH surge was higher in sheep of the prolific Romanov breed than in less prolific Ile-de-France ewes (Cahill et al., 1981), suggesting that concentrations of FSH early in the oestrous cycle might be related to later growth of follicles. To our knowledge, the relationship of this periovulatory rise in FSH to subsequent follicular development in cattle has not been examined previously.

Ultrasonographic studies have shown that follicular growth in heifers occurs in 2 or 3 successive waves per oestrous cycle (Fortune et al., 1988; Savio et al., 1988; Sirois \& Fortune, 1988; Knopf et al., 1989). Each wave of growth is characterized by the recruitment of a group of follicles, with selection of one large dominant follicle. It is usually the dominant follicle of the third wave that ovulates. The precise endocrine control of these patterns of follicular recruitment, selection, growth and regression, particularly during the early and mid-luteal phase, remains a mystery.

Bovine follicular fluid (bFF) contains the glycoprotein inhibin (Robertson et al., 1985) which selectively suppresses the synthesis and secretion of FSH from pituitary cells in vitro (see de Jong, 1988). Injection of bFF suppressed circulating concentrations of FSH in vivo without altering plasma LH in ovariectomized (Ireland et al., 1983) and intact (Quirk \& Fortune, 1986) heifers. In the present study, bFF was used to suppress the secondary FSH surge in order to examine the role of this increase in FSH in determining patterns of follicular development in the heifer. A brief report has appeared in abstract form (Turzillo \& Fortune, 1989).

\section{Materials and Methods}

Animals. Holstein heifers were housed in a stanchion barn and were fed a diet of corn silage and hay with mineral supplement. Experiments were conducted during the months of October, January and May using 11 animals that had exhibited at least 2 consecutive, natural oestrous cycles of normal length just before the experiment.

Experimental design. Oestrus was synchronized by a single intramuscular injection of $25 \mathrm{mg}$ prostaglandin F-2 $\alpha$ (PGF-2 $\alpha$, Lutalyse: Upjohn Co., Kalamazoo, MI, USA) during the mid-luteal phase (Day 10 to Day 15) of the oestrous cycle (Day $0=$ oestrus). Beginning $48 \mathrm{~h}$ after PGF- $2 \alpha$ injection, heifers were observed for oestrous behaviour at 4-h intervals. Onset of oestrus was identified as the first observation period when a heifer would stand to be mounted by another heifer. Six heifers were treated with $10 \mathrm{ml}$ charcoal-extracted bovine follicular fluid (bFF, preparation described below) i.v. at 12-h intervals from 12 to $60 \mathrm{~h}$ after onset of oestrus. Five control animals received $10 \mathrm{ml} 0.9 \%$ saline $(0.154 \mathrm{M}-\mathrm{NaCl})$ injections in the same fashion. Collection of blood samples via jugular cannulae (Abbocath; $14 \mathrm{G} \times 14.0 \mathrm{~cm}$, Abbott Hospitals Inc., North Chicago, IL, USA) began $48 \mathrm{~h}$ after PGF-2 $\alpha$ injection and was continued at $4-\mathrm{h}$ intervals until $132 \mathrm{~h}$ after onset of oestrus. Heparin-saline $(200 \mathrm{i} . \mathrm{u} . / \mathrm{ml})$ was used to fill cannulae after each sample was taken. Daily samples were collected by venepuncture for the remainder of the oestrous cycle. Plasma was harvested from all samples and stored at $-20^{\circ} \mathrm{C}$ for later measurement of $\mathrm{FSH}, \mathrm{LH}$, progesterone and oestradiol-17ß by radioimmunoassays (RIA).

Ultrasonographic examinations of ovaries were performed daily using a real-time B-mode linear array ultrasound scanner equipped with a $7.5 \mathrm{MHz}$ intrarectal probe (Technicare 210DX; Corametrics, North Branford, CT, USA). The procedure used in our laboratory for monitoring ovarian follicular dynamics has been described previously in detail (Quirk et al., 1986; Sirois \& Fortune, 1988). Heifers were not anaesthetized or restrained during examinations. Examinations were recorded on videotape (Ampex Videocassette; Ampex Corp., Redwood City, CA, USA) and subsequently reviewed on a video monitor (Panasonic NV8950; Matsushita Electric Corp., Secaucus, NJ, USA). Diameters of the antral cavities of all follicles with antral cavities $\geq 5 \mathrm{~mm}$ in diameter and diameters of corpora lutea were recorded. Identification of individual follicles was achieved by examining their locations on the ovary relative to other structures (follicles and corpora lutea) and to the dorsal, ventral, medial and lateral surfaces of the ovary. Thus patterns of growth and regression of individual follicles were followed day by day throughout the entire experimental period; ultrasonographies began on the day of PGF- $2 \alpha$ injection and continued until ovulation had occurred at the beginning of the oestrous cycle after bFF or saline treatment. Ovulation was identified by the disappearance of a large follicle preceded by behavioural oestrus.

bFF preparation. Bovine follicular fluid was collected at a slaughterhouse (Taylor Packing Co., Wyalusing, PA, USA) by aspiration of ovarian follicles $<20 \mathrm{~mm}$ in diameter. Fluid was kept on ice at all times and transported to the 
laboratory where it was centrifuged at $2400 \mathrm{~g}$ for $30 \mathrm{~min}$ at $4^{\circ} \mathrm{C}$ (to remove cellular debris) and then stored at $-20^{\circ} \mathrm{C}$. All bFF collections were thawed and pooled for charcoal-extraction of steroids (Quirk \& Fortune, 1986). Follicular fluid was stirred at room temperature for $45 \mathrm{~min}$ with $50 \mathrm{mg}$ charcoal $/ \mathrm{ml}$ (Norit-A; Thomas Scientific, Swedesboro, $\mathrm{NJ}$, USA) and then centrifuged at $12000 \mathrm{~g}$ for $1 \mathrm{~h}$ at $4^{\circ} \mathrm{C}$. To remove remaining charcoal particles, the fluid was filtered through glass-fibre filter paper. The extracted bFF pool was refrozen and stored at $-20^{\circ} \mathrm{C}$. This charcoal extraction procedure reduced oestradiol and progesterone concentrations in the follicular fluid from 63.7 to $0.03 \mathrm{ng} / \mathrm{ml}$ and from 66.3 to $0.65 \mathrm{ng} / \mathrm{ml}$, respectively.

Hormone assays. FSH concentrations in plasma were quantified by an homologous RIA (Bolt \& Rollins, 1983; Butler et al., 1983; Quirk \& Fortune, 1986). Reagents were obtained from the USDA Animal Hormone Program. These included antiserum to the bovine FSH- $\beta$ subunit (USDA-5-0122), immunochemical grade FSH for preparation of labelled ligand (USDA-FSH-BP3), and biological grade FSH for standard (USDA-bFSH-B-1; biological potency $1.7 \times$ NIH-FSH-B1). FSH was radioiodinated using Iodogen (Pierce Chemical Co., Rockford, IL, USA). The second antibody was goat anti-rabbit immunoglobulin G (ICN Immunobiologicals, Lisle, IL, USA). Aliquants of $300 \mu \mathrm{l}$ plasma were assayed in duplicate. The sensitivity of the FSH RIA was $1.44 \mathrm{ng}$ per assay tube with an intra-assay coefficient of variation (CV) of $9 \cdot 3 \%$ and an inter-assay CV of $8 \cdot 4 \%$.

Plasma concentrations of LH were measured by RIA (Niswender et al., 1969) using antiserum to ovine LH (CSU204) provided by Dr G. D. Niswender. Highly purified ovine LH (LER-1056-C2) supplied by Dr L. E. Reichert, Jr was radioiodinated using chloramine-T. The standard preparation was bovine LH (NIH-LH-B9). The second antibody was the same as that used in the FSH RIA. Aliquants of $200 \mu$ plasma were assayed in duplicate. The sensitivity of this assay was $0.13 \mathrm{ng}$ per assay tube, the intra-assay CV was $6.7 \%$, and the inter-assay CV was $8.6 \%$.

Progesterone was quantified in plasma samples by specific RIA (Beal et al., 1980). Duplicate $100 \mu l$ samples were extracted with petroleum ether. The recovery of tritiated progesterone added to bovine plasma was $75.5 \pm 1.9 \%$ and the solvent blank was negligible. Assay values were not corrected for recovery. The sensitivity of this assay was $12.5 \mathrm{pg}$ per assay tube, the intra-assay CV was $8.3 \%$ and the inter-assay CV was $9 \cdot 7 \%$.

Oestradiol-17ß (oestradiol) was measured in plasma samples using a modification of a commercially-available RIA (Second Antibody Estradiol; Diagnostic Products Corp., Los Angeles, CA, USA) recently validated for use in our laboratory. This assay method utilizes a specific oestradiol antiserum that exhibits very low cross-reactivities with related steroids (oestriol, $0.24 \%$; androstenedione, $0.004 \%$; progesterone and testosterone, not detectable). Iodinated oestradiol serves as labelled ligand, and goat anti-rabbit gamma globulin with polyethyleneglycol ("precipitating solution') is used to separate bound and free ligand. Oestradiol standards $(0 \cdot 156-40 \mathrm{pg})$ diluted in assay buffer $(0 \cdot 1 \%$ gelatin in phosphate-buffered saline) were prepared in our laboratory and substituted for the commercially available standard. Duplicate aliquants of $200 \mu \mathrm{l}$ plasma were extracted with $2 \mathrm{ml}$ diethyl ether. Recovery of iodinated oestradiol added to bovine plasma was $86 \cdot 2 \pm 1.7 \%$ and the solvent blank was negligible. Values were not corrected for recovery. Extracts were dried under nitrogen, reconstituted in $200 \mu$ l assay buffer and stored overnight at $4^{\circ} \mathrm{C}$ to precipitate lipids. A $100-\mu \mathrm{l}$ sample was removed from each reconstituted extract and assayed. To conduct the assay, anti-oestradiol antiserum $(30 \mu \mathrm{l})$ was added to standards and extracted samples and incubated at room temperature for $2 \mathrm{~h}$. Iodinated oestradiol $(75 \mu \mathrm{l}$ or 25000 c.p.m.) was then added and the incubation continued for $1 \mathrm{~h}$ at room temperature. A 10 -min incubation with $1 \mathrm{ml}$ precipitating solution was followed by centrifugation at $2400 \mathrm{~g}$ for $20 \mathrm{~min}$. Supernatants were decanted and precipitates counted. When aliquants of plasma from an ovariectomized heifer containing $0 \cdot 17,0 \cdot 50,1.50$ or $4.50 \mathrm{pg}$ exogenous oestradiol $/ 100 \mu \mathrm{l}$ were extracted and assayed, $0.25 \pm 0.01$, $0.61 \pm 0.03,2 \cdot 12 \pm 0.06$ and $5.5 \pm 0.16 \mathrm{pg} / 100 \mu \mathrm{l}$, respectively, were measured $(n=20)$. Oestradiol concentration in the plasma of the ovariectomized heifer (without added oestradiol) was near the limit of sensitivity of the assay $(0.08 \pm 0.01 \mathrm{pg} / 100 \mu \mathrm{l} ; n=20)$. Concentrations of oestradiol in samples assayed using this method were comparable to values previously derived from an established assay procedure in which extracts of the same samples were chromatographed before RIA (Quirk \& Fortune, 1986). Regression of values obtained using the new method on those from the previous method yielded the equation $y=-0.013 \mathrm{pg}+1 \cdot 007 x\left(r^{2}=0.8 \mathrm{l} ; P<0.001\right)$. Sensitivity of this assay method, calculated as 2 standard deviations below the mean c.p.m. at maximum binding, is $0.079 \mathrm{pg} /$ assay tube $(0.79 \mathrm{pg} / \mathrm{ml}$ plasma). The intra-assay $\mathrm{CV}$ was $15.2 \%$ and the inter-assay $\mathrm{CV}$ was $16.0 \%$.

Statistical analyses. Differences in plasma concentrations of hormones between control and bFF-treated heifers were assessed by a general linear model split-plot analysis of variance, with a multivariate analysis for effects of time (repeated measures) and interaction with treatments (SAS Users Guide: Statistics, 1985). Student's $t$ test was used to analyse effects of bFF treatment on oestrous cycle length and on parameters of ovarian follicular growth and regression. With the exception of data describing numbers of waves of follicular growth, all values are presented as mean \pm s.e.m.

\section{Results}

\section{Effects of bFF on plasma hormone concentrations}

Following the preovulatory FSH surge, control heifers exhibited the expected secondary elevation in plasma FSH before concentrations returned to baseline (Fig. 1a). Treatment with bFF consistently suppressed circulating FSH. From 12 to $72 \mathrm{~h}$ after onset of oestrus, plasma FSH was 
lower in bFF-treated animals $(P<0.01)$, indicating that the secondary FSH surge had been suppressed. Cessation of bFF injections was followed by a rebound in plasma FSH. A significant time $\times$ treatment interaction was observed during the period $72-132 \mathrm{~h}$ after onset of oestrus $(P<0.01)$, and plasma FSH was significantly elevated in bFF-treated heifers from 80 to $104 \mathrm{~h}$ as compared with controls $(P<0.01)$. Since a preovulatory surge of FSH was identifiable in each heifer before injections were initiated, neither saline nor bFF treatment affected this event. Plasma FSH concentrations before treatments did not differ between groups.
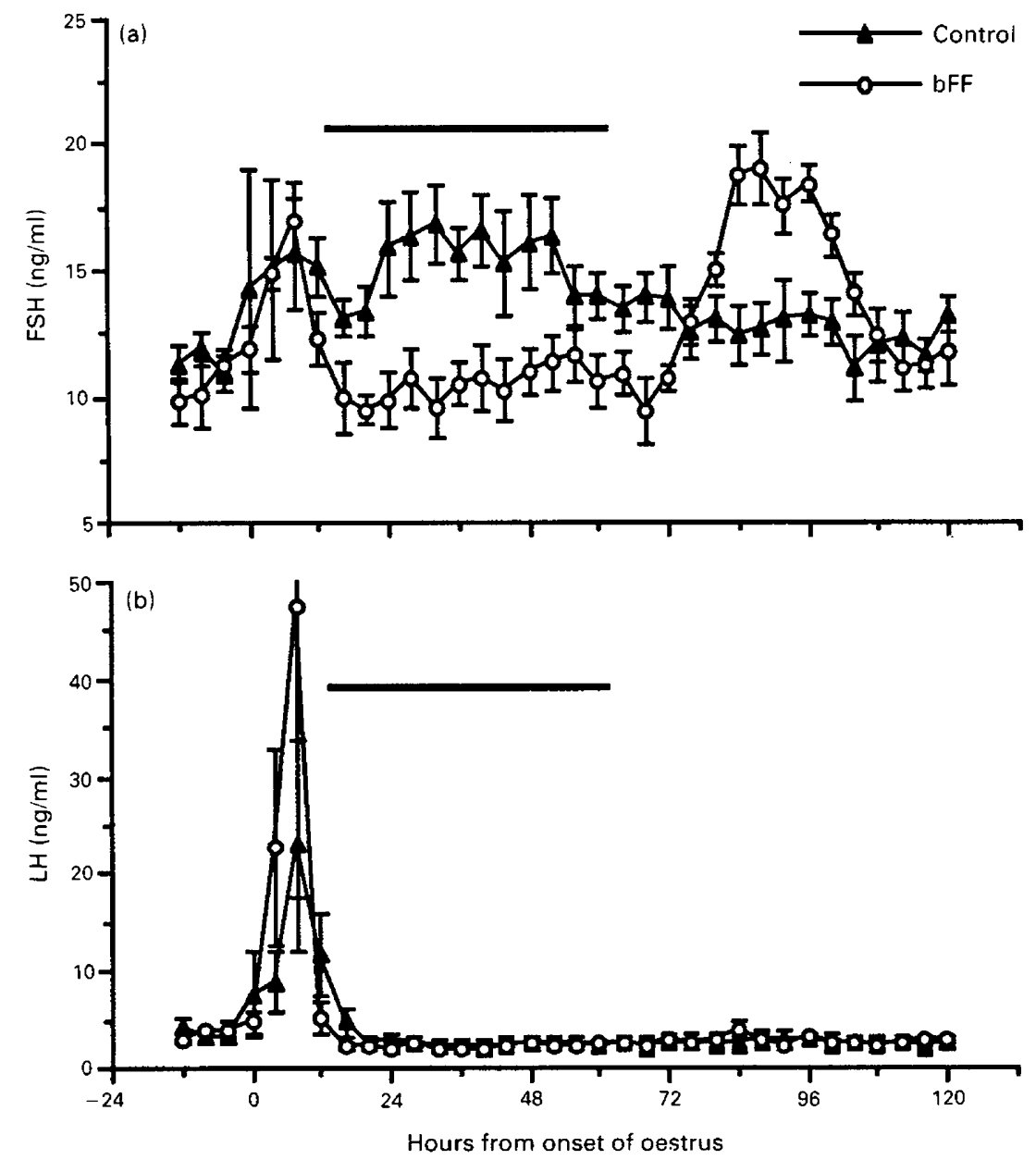

Fig. 1. Concentrations of (a) FSH and (b) $\mathrm{LH}$ (mean \pm s.e.m.) in samples of plasma collected at 4-h intervals from heifers injected with $10 \mathrm{ml}$ bovine follicular fluid (bFF) or $10 \mathrm{ml}$ saline (control) every $12 \mathrm{~h}$ during the injection period indicated by the horizontal bars.

No differences in circulating concentrations of $\mathrm{LH}$ were detectable between groups before, during or after bFF or saline treatment (Fig. 1b). All heifers exhibited evidence of a preovulatory LH surge. Plasma progesterone profiles and daily concentrations throughout the oestrous cycle did not differ between saline- and bFF-treated animals (data not shown), indicating normal development of corpora lutea by heifers in both treatment groups.

Small increases in plasma oestradiol were observed during the early luteal phase in both treatment groups (Fig. 2). This increase occurred earlier in control heifers than in heifers treated with 


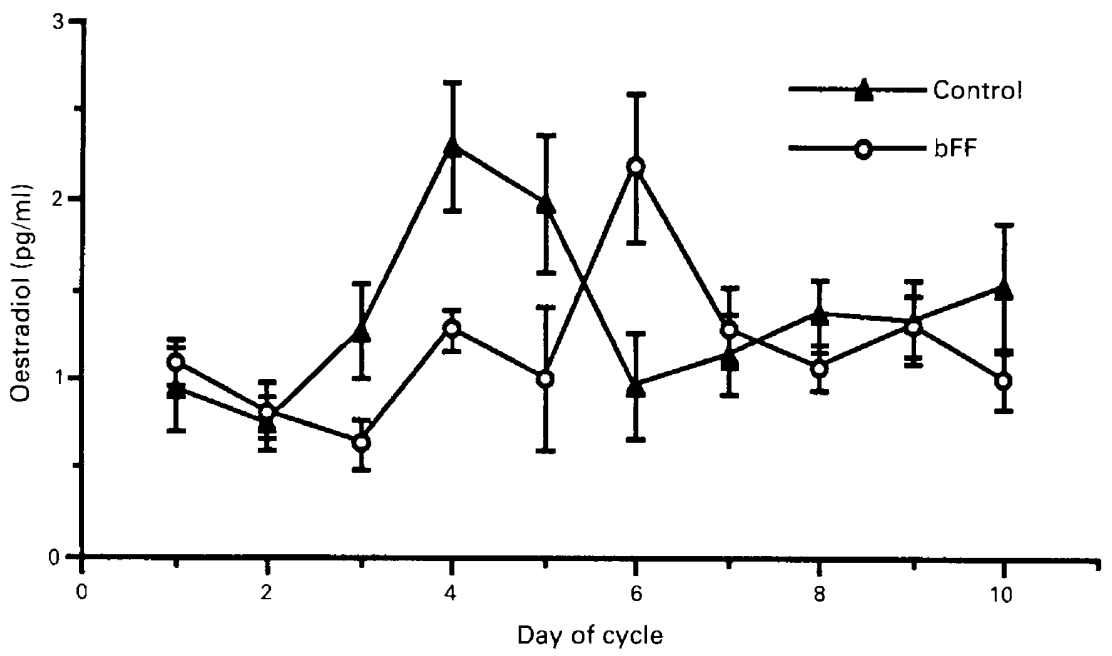

Fig. 2. Concentrations of oestradiol- $17 \beta$ (mean \pm s.e.m.) in plasma from heifers treated with bovine follicular fluid (bFF) or saline (control).

Table 1. Characteristics of the dominant follicle of the first wave of follicular development

\begin{tabular}{lcc}
\hline & Control & $\begin{array}{c}\text { bFF } \\
\text { treatment }\end{array}$ \\
\hline $\begin{array}{l}\text { Day of appearance } \\
\text { Day maximal size } \\
\text { reached }\end{array}$ & $1 \cdot 8 \pm 0 \cdot 2^{* * *}$ & $4 \cdot 5 \pm 0 \cdot 3^{* * *}$ \\
$\begin{array}{l}\text { Maximal size } \dagger \\
(\mathrm{mm})\end{array}$ & $9 \cdot 2 \pm 0 \cdot 8$ & $10 \cdot 5 \pm 0 \cdot 4$ \\
$\begin{array}{l}\text { Persistence } \\
\text { (days) }\end{array}$ & $14 \cdot 1 \pm 0 \cdot 9$ & $13 \cdot 0 \pm 0 \cdot 5$ \\
$\begin{array}{l}\text { Growth rate } \\
\text { (mm/day) }\end{array}$ & $18 \cdot 6 \pm 1 \cdot 5$ & $15 \cdot 2 \pm 1 \cdot 1$ \\
\hline $\begin{array}{l}\text { Values are means } \pm \text { s.e.m. for } 5 \text { control or } 6 \text { bFF-treated } \\
\text { heifers. }\end{array}$ & $1 \cdot 5 \pm 0 \cdot 1$ & $1 \cdot 4 \pm 0 \cdot 1$ \\
$* * * P<0.0001$ compared with respective control. \\
+ Diameter of antrum only.
\end{tabular}

bFF (peak concentrations on Day $4.2 \pm 0.20$ and Day $6 \cdot 3 \pm 0 \cdot 6$, respectively; $P<0.05$ ), resulting in a significant time $\times$ treatment interaction $(P<0.01)$.

\section{Effects of bFF on follicular dynamics}

Suppression of the secondary FSH surge was associated with altered patterns of ovarian follicular dynamics. Of the 6 heifers treated with bFF, $5(83 \cdot 3 \%)$ exhibited 2 waves of follicular development during the oestrous cycle in which the secondary surge was suppressed, and 1 exhibited 3 waves. This contrasted with the control group in which 4 heifers $(80 \%)$ exhibited 3 waves and only 1 heifer had 2 waves. These differences in numbers of waves per oestrous cycle were not accompanied by differences in mean cycle length $(21.8 \pm 0.4$ days in control heifers and $21 \cdot 2 \pm 0.8$ days in bFF-treated heifers). Ovulations were evident on Day 1 or 2 of the oestrous cycle after bFF or saline treatment. All heifers ovulated a single follicle except control Heifer 461, which ovulated two follicles (Fig. 3). 

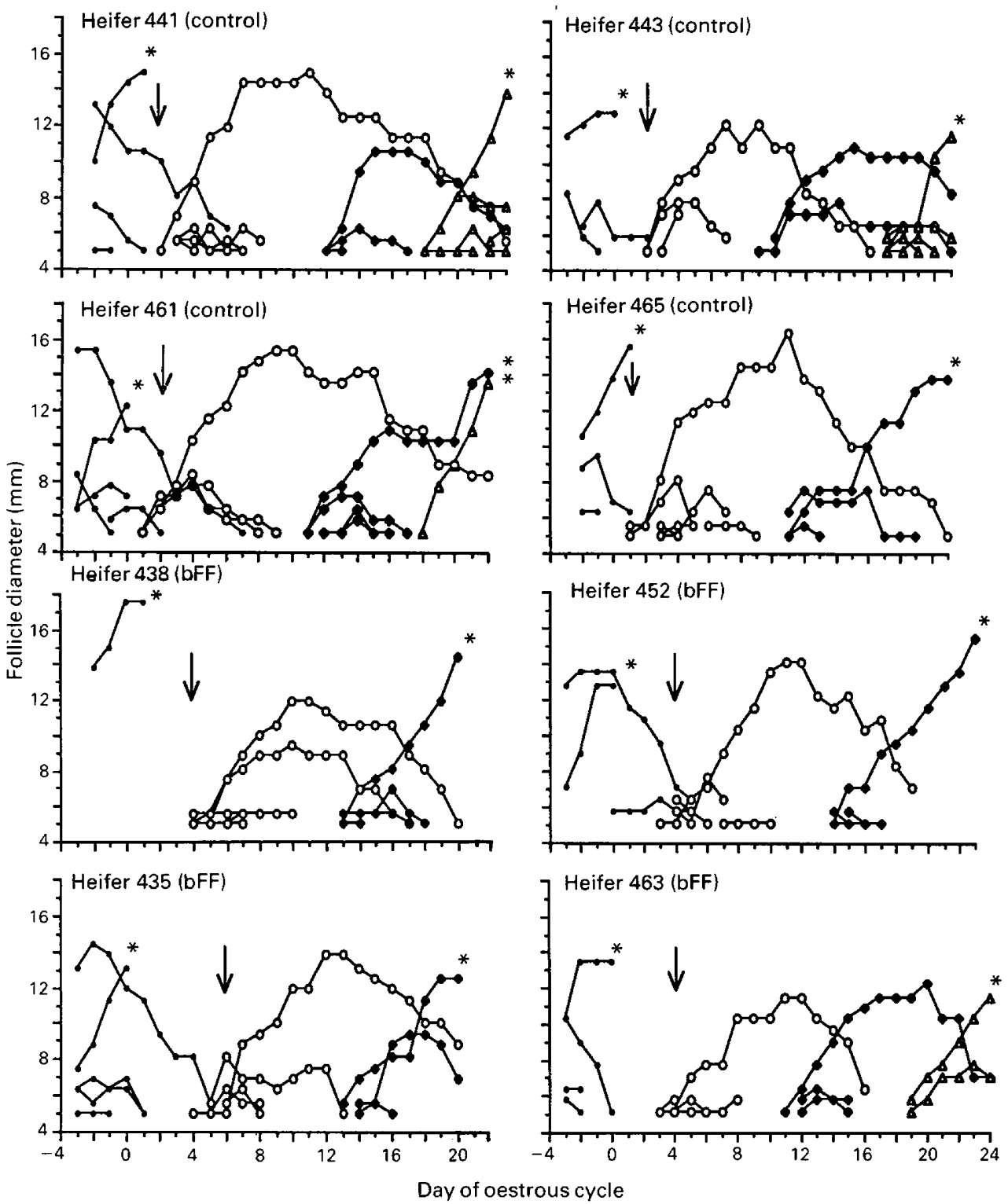

Fig. 3. Patterns of growth and regression of individual follicles throughout complete oestrous cycles of 4 control heifers and 4 bFF-treated heifers. Arrows indicate day of appearance of dominant follicles in the first wave of follicular development. Asterisks denote ovulatory follicles. Only follicles with antral diameters of $5 \mathrm{~mm}$ or greater for a minimum of 2 consecutive days are represented. Symbols denote follicles from the previous cycle (- - ) and follicles in the first $(-\mathrm{O}-)$, second $(-\bullet)$, and third $(-\triangle-)$ waves.

Appearance of the first wave of follicular growth was significantly delayed by bFF treatment (Fig. 3). In control heifers, newly recruited follicles ( $\geq 5 \mathrm{~mm}$ in diameter) were first visible on Day 1 or Day 2 of the oestrous cycle (Day 1.4 \pm 0.2 ). New follicles were not present in the ovaries of bFFtreated heifers before Day 2, and usually appeared on Day 3 or 4 (Day $3.3 \pm 0.3 ; P<0.0001$ ). Appearance of the first morphologically dominant follicle, defined as the day on which it could be 
Table 2. Characteristics of the dominant follicle of the second wave of follicular development

\begin{tabular}{lcc}
\hline & Control & $\begin{array}{c}\text { bFF } \\
\text { treatment }\end{array}$ \\
\hline $\begin{array}{l}\text { Day of appearance } \\
\text { Day maximal size } \\
\text { reached }\end{array}$ & $10 \cdot 6 \pm 0 \cdot 5^{* *}$ & $13 \cdot 0 \pm 0.5^{* *}$ \\
$\begin{array}{l}\text { Maximal size } \\
\text { (mm) }\end{array}$ & $17 \cdot 0 \pm 1 \cdot 7$ & $20 \cdot 3 \pm 0 \cdot 7$ \\
$\begin{array}{l}\text { Persistence } \\
\text { (days) }\end{array}$ & $11 \cdot 4 \pm 1 \cdot 2^{*}$ & $14 \cdot 6 \pm 0.8^{*}$ \\
$\begin{array}{l}\text { Growth rate } \\
\text { (mm/day) }\end{array}$ & $11 \cdot 2 \pm 0 \cdot 4^{*}$ & $8 \cdot 5 \pm 1 \cdot 1^{*}$ \\
\hline
\end{tabular}

Values are means \pm s.e.m. for 5 control or 6 bFF-treated heifers.

${ }^{*} P<0.05$ compared with respective control.

$* * P<0.0$ l compared with respective control.

$\dagger$ Diameter of antrum only.

retrospectively identified with a diameter of $\geq 5 \mathrm{~mm}$, was also delayed significantly by bFF treatment $(P<0.0001$; Table 1$)$. The day of the oestrous cycle on which this follicle reached maximal size, maximal size of the follicle, its persistence (total number of days the follicle could be identified with a diameter $\geq 5 \mathrm{~mm}$ ) and growth rate were not affected by bFF treatment. In control heifers, the dominant follicle of the first wave became visible either on the same day as the other follicles in its cohort or on the following day. The mean difference between appearance of newly recruited follicles and that of the first dominant follicle in the controls was $0.4 \pm 0.2$ days. This difference tended to be greater in bFF-treated animals, in which the dominant follicle usually appeared 1-2 days later than others in its cohort (mean difference $=1.2 \pm 0.3$ days; $P=0.087$ ).

Characteristics of the second wave of follicular growth were also altered by bFF. New follicles appeared later in bFF-treated heifers (Day 12.7 \pm 0.4 compared with Day $10.4 \pm 0.6$ in controls, $P<0.01)$. Appearance of the second dominant follicle was also delayed in bFF-treated heifers $(P<0.01)$, and its maximal size was greater $(P<0.05$; Table 2$)$. The dominant follicle of the second wave tended to reach maximal size later in the oestrous cycle $(P=0.064)$, and was on average less persistent in bFF-treated animals $(P<0.05)$. No differences in growth rates of the second dominant follicles were found between treatment groups. Appearance of dominant follicles in the second wave was not delayed relative to that of others in their respective cohorts.

Heifers treated with $\mathrm{bFF}$ tended to have greater total numbers of follicles with diameters $\geq 5 \mathrm{~mm}$ (including dominant follicles) per wave of follicular growth. In the first wave, $6 \cdot 6 \pm 1 \cdot 2$ follicles were detected in control animals while bFF-treated heifers had $10 \cdot 2 \pm 1.4$ follicles $(P=$ $0.086)$. In the second wave of growth, $5.0 \pm 0.6$ follicles were observed in controls, compared with $6.8 \pm 0.8$ in heifers receiving follicular fluid $(P=0.084)$. Because only 1 of 6 heifers receiving bFF treatment exhibited 3 waves of follicular growth (Heifer 463), valid statistical comparisons regarding numbers of follicles and characteristics of dominant follicles in the third wave were not possible.

\section{Discussion}

Injections of bFF consistently suppressed the secondary FSH surge normally observed in heifers. Associated with this suppression were delays in follicular development, suggesting that the periovulatory increase in FSH secretion may play an important role in regulating patterns of ovarian 
follicular growth in cattle. To our knowledge, this is the first report linking the secondary FSH surge with follicular dynamics during the bovine oestrous cycle.

The endocrine responses to bFF observed in this study (Fig. 1) confirm previous results demonstrating in vivo the selective suppressive effect of charcoal-extracted bFF on FSH secretion in the absence of an effect on LH in female cattle (Ireland et al., 1983; Johnson et al., 1985; Quirk \& Fortune, 1986). The dose of follicular fluid used suppressed plasma FSH during the normal time of the secondary surge to basal concentrations (i.e. concentrations in controls after the secondary surge). This magnitude of suppression was an important factor, since we did not wish to deprive follicles of basal gonadotrophin support by driving FSH below normal concentrations.

The significant elevation in plasma FSH concentrations over those of controls after the final bFF injections is similar to rebounds in FSH secretion described previously following treatment of intact heifers (Quirk \& Fortune, 1986; Johnson \& Smith, 1985) and ewes (Miller et al., 1982; McNeilly, 1984, 1985; Wallace \& McNeilly, 1985) with bFF. Although the reasons for the rebound effect are not completely understood, it seems that this transient increase in plasma FSH is related to the presence of the ovaries, since a rebound was not reported following bFF-induced suppression of FSH in ovariectomized heifers (Ireland et al., 1983) or in ovariectomized ewes treated with bFF or pure bovine inhibin (Findlay et al., 1987). The rebound may reflect altered feedback relationships due to delayed follicular development (and hence lower endogenous production of inhibin and oestradiol). Because the rebound in plasma FSH observed in bFF-treated heifers in this study resembled the secondary FSH surge in controls, bFF-treatment in effect delayed the secondary surge of FSH by approximately 2 days.

In heifers treated with bFF the appearance of new follicles $\geq 5 \mathrm{~mm}$ in diameter was delayed by about 2 days, suggesting that follicular recruitment for the first wave was delayed by suppression of the secondary FSH surge. This wave tended to consist of more follicles than the first wave of growth in control heifers, and these 'extra' follicles were probably recruited in response to the rebound of FSH, because plasma concentrations were usually elevated above those of controls around the time of appearance of new follicles in bFF-treated heifers. Concomitant with the delayed growth of new follicles was a delay in the appearance of the first dominant follicle following bFF treatment, suggesting that the secondary FSH surge may be important in initiating normal development of this follicle. In addition, it is possible that selection of the first dominant follicle was also affected by decreased FSH, since it tended to appear later than others in the first recruited cohort relative to the appearance of the dominant follicle in control heifers. These ideas are speculative, however, because there may be critical steps in follicular recruitment and selection that occur in the smaller, gonadotrophin-sensitive populations (Richards, 1980; Ireland, 1987) which cannot be accurately monitored by current ultrasonographic techniques.

Oestradiol was measured in samples taken during the first 10 days of the cycle to determine whether the delay in the first wave of follicular development in bFF-treated heifers was accompanied by changes in plasma oestradiol. The small increase observed in peripheral blood concentration during the early luteal phase confirms previous reports (Shemesh et al., 1972; Glencross et al., 1973). Ireland \& Roche (1983) have shown that single oestrogenic follicles are present in the ovary during early dioestrus. These follicles are presumably responsible for the rise of oestradiol detectable in the peripheral circulation at this time. The delayed growth of the first dominant follicle following bFF treatment compared with that of controls was clearly reflected in a corresponding delayed increase in oestradiol, with peak plasma concentrations occurring approximately 2 days after appearance of the first dominant follicle in both groups.

Although the development of the first dominant follicle was delayed by treatment with $\mathrm{bFF}$, its eventual morphological dominance was accompanied by a period of several days when no new follicles were recruited (Fig. 3). This observation illustrates the concept of functional dominance, the ability to inhibit further growth of antral follicles (Ireland \& Roche, 1987). Because this period of functional dominance during the first wave of follicular growth was similar in both treatment groups, the delayed appearance of follicles in the second wave in bFF-treated heifers was probably 
not a direct result of suppression of the secondary FSH surge, but rather an indirect consequence of the delay in the onset of the first wave. The larger average size and shorter persistence of the second dominant follicles in these animals can be explained by the fact that most $(5 / 6)$ were ovulatory follicles, which have been shown to reach greater maximal diameters than the non-ovulatory dominant follicles usually observed during the second wave (Savio et al., 1988; Sirois \& Fortune, 1988). In contrast, only 1 of 5 second dominant follicles in control heifers was the ovulatory follicle.

Four of 5 control heifers $(80 \%)$ exhibited 3 waves of follicular development during the cycle after prostaglandin synchronization, while the remaining heifer had 2 waves. Although 5 animals is a relatively small sample, these results confirm those of Savio et al. (1988) and Sirois \& Fortune (1988), who reported that the majority of heifers examined ultrasonographically during natural oestrous cycles also exhibited 3 waves of growth. This common pattern was altered in heifers treated with bFF, with 5 of 6 animals exhibiting only 2 waves of follicular development. The lack of effect of bFF on plasma progesterone and length of oestrous cycles indicates that formation and function of corpora lutea were not impaired by bFF and that luteolysis occurred normally. Therefore, although the usual pattern of follicular development was delayed by bFF treatment, the time of luteal regression was not altered and consequently occurred while the dominant follicle of the second wave was present, leading to ovulation of that follicle. The only animal (Heifer 463) in the bFF-treated group that exhibited 3 waves also had the longest oestrous cycle ( 24 days), suggesting that the slightly longer luteal lifespan provided time for recruitment of a third wave and subsequent ovulation of the third dominant follicle.

Follicular fluid is a complex mixture containing a myriad of non-steroidal substances with potential functions in the regulation of folliculogenesis. These substances include inhibin, activins, FSH binding inhibitor, follicle regulatory protein, and growth factors (see Ireland, 1987; Tsafriri, 1988, for reviews). Such components have been implicated in the inhibition of gonadotrophinstimulated follicle growth in follicular fluid-treated rats (Kling et al., 1984) and ewes (Cahill et al., 1985). In contrast, other studies failed to demonstrate negative effects on follicular growth when bFF and exogenous FSH were administered together (McNeilly, 1985; Moser et al., 1989). We cannot ignore the possibility that inhibin or other factors in our preparation of bFF may have affected follicular development directly, independent of changes in pituitary FSH secretion. However, the consistent and significant delays in development of follicles associated with specific suppression of plasma FSH in this study suggest that the secondary FSH surge is important in reinitiating waves of follicular development following ovulation, and thus plays a role in the regulation of patterns of ovarian follicular development in cattle.

We thank J. Roycroft and S. Vincent for outstanding technical assistance; Dr M. M. Hinshelwood for help during collection of blood samples; Dr W. R. Butler for advice on RIA procedures; and Dr W. B. Currie and Dr W. Hansel for suggestions during preparation of this manuscript. Reagents used in assays were kindly provided by Dr D. J. Bolt of the USDA Animal Hormone Program, Dr G. D. Niswender and Dr L. E. Reichert, Jr. The cooperation of Taylor Packing Co, Wyalusing, PA during collection of bFF is gratefully acknowledged.

This study was supported by USDA Grant 86-CRCR-1-2125.

\section{References}

Beal, W.E., Milvae, R.A. \& Hansel, W. (1980) Oestrous cycle length and plasma progesterone concentrations following adminstration of prostaglandin F-2 $\alpha$ early in the bovine oestrous cycle. J. Reprod. Fert. 59, $393-396$.

Bolt, D.J. \& Rollins, R. (1983) Development and application of a radioimmunoassay for bovine folliclestimulating hormone. J. Anim. Sci. 56, 146-154.

Butler, W.R., Katz, L.S., Arriola, J., Milvae, R.A. \&
Foote, R.H. (1983) On the negative feedback regulation of gonadotrophins in castrate and intact cattle with comparison of two FSH radioimmunoassays. $J$. Anim. Sci. 56, 919-929.

Cahil, L.P., Saumande, J., Ravault, J.P., Blanc, M., Thimonier, J., Mariana, J.C. \& Mauléon, P. (1981) Hormonal and follicular relationships in ewes of high and low ovulation rates. J. Reprod. Fert. 62, $141-150$.

Downloaded from Bioscientifica.com at 04/26/2023 08:29:33AM 
Cahill, L.P., Driancourt, M.A., Chamley, W.A. \& Findlay, J.K. (1985) Role of intrafollicular regulators and FSH in growth and development of large antral follicles in sheep. J. Reprod. Fert. 75, 599-607.

de Jong, F.H. (1988) Inhibin. Physiol. Rev. 68, 555-607.

Dobson, H. (1978) Plasma gonadotrophins and oestradiol during oestrus in the cow. J. Reprod. Fert. 52, 51-53.

Findlay, J.K., Robertson, D.M. \& Clarke, I.J. (1987) Influence of dose and route of administration of bovine follicular fluid and the suppressive effect of purified bovine inhibin $\left(M_{\mathrm{r}} 31000\right)$ on plasma FSH concentrations in ovariectomized ewes. $J$. Reprod. Fert. 80, 455-461.

Fortune, J.E., Sirois, J. \& Quirk, S.M. (1988) The growth and differentiation of follicles during the bovine estrous cycle. Theriogenology 29, 95-109.

Glencross, R.G., Munro, I.B., Senior, B.E. \& Pope, G.S. (1973) Concentrations of oestradiol-17 $\beta$, oestrone and progesterone in jugular venous plasma of cows during the oestrous cycle and in early pregnancy. Acta endocr., Copenh. 73, 374-384.

Grady, R.R., Charlesworth, M.C. \& Schwartz, N.B. (1982) Characterization of the FSH-suppressing activity in follicular fluid. Recent Prog. Horm. Res. 38, 409-447.

Greep, R., VanDyke, H.B. \& Chow, B.F. (1942) Gonadotrophins of the swine pituitary. I. Various biological effects of purified thylakentrin (FSH) and pure metakentrin (ICSH). Endocrinology 30, 635-649.

Ireland J.J. (1987) Control of follicular growth and development. J. Reprod. Fert., Suppl. 34, 39-54.

Ireland, J.J. \& Roche, J.F. (1983) Development of nonovulatory antral follicles in heifers: changes in steroids in follicular fluid and receptors for gonadotrophins. Endocrinology 112, 150-156.

Ireland, J.J. \& Roche, J.F. (1987) Hypotheses regarding development of dominant follicles during a bovine estrous cycle. In Follicular Growth and Ovulation Rate in Farm Animals, pp. 1-18. Eds J. F. Roche \& D. O'Callaghan. Martinus Nijhoff Publishers, Dordrecht.

Ireland, J.J., Curato, A.D. \& Wilson, J. (1983) Effect of charcoal-treated bovine follicular fiuid on secretion of LH and FSH in ovariectomized heifers. J. Anim. Sci. 57, 1512-1516.

Johnson, S.K. \& Smith, M.F. (1985) Effects of charcoalextracted, bovine follicular fluid on gonadotropin concentrations, the onset of estrus and luteal function in heifers. J. Anim. Sci. 61, 203-209.

Johnson, S.K., Smith, M.F. \& Elmore R.G. (1985) Effect of unilateral ovariectomy and injection of bovine follicular fluid on gonadotropin secretion and compensatory ovarian hypertrophy in prepuberal heifers. J. Anim. Sci. 60, 1055-1060.

Kling, O.R., Roche, P.C., Campeau, J.D., Nishimura, K., Nakamura, R.M. \& diZerega, G.S. (1984) Identification of a porcine follicular fluid fraction which suppresses follicular response to gonadotrophins. Biol. Reprod. 30, 564-572.

Knopf, L., Kastelic, J.P., Schallenberger, E. \& Ginther, O.J. (1989) Ovarian follicular dynamics in heifers: test of two-wave hypothesis by ultrasonically monitoring individual follicles. Dom. Anim. Endocr. 6, $111-119$.

McNeilly, A.S. (1984) Changes in FSH and the pulsatile secretion of $\mathrm{LH}$ during the delay in oestrus induced by treatment of ewes with bovine follicular fluid. $J$. Reprod. Fert. 72, 165-172.

NeNeilly, A.S. (1985) Effect of changes in FSH induced by bovine follicular fluid and FSH infusion in the preovulatory phase on subsequent ovulation rate and corpus luteum function in the ewe. J. Reprod. Fert. 74, 661-668.

Miller, K.F., Critser, J.K. \& Ginther, O.J. (1982) Inhibition and subsequent rebound of FSH secretion following treatment with bovine follicular fluid in the ewe. Theriogenology 18, 45-53.

Moser, M.T., Garverick, H.A., Smith, M.F. \& Youngquist, R.S. (1989) Effect of bovine follicular fluid and follicle-stimulating hormone on follicular growth in unilaterally ovariectomized prepuberal heifers. J. Dairy Sci. 72, 2170-2178.

Niswender, G.D., Reichert, L.E., Jr, Midgley, A.R., Jr \& Nalbandov, A.V. (1969) Radioimmunoassay for bovine and ovine luteinizing hormone. Endocrinology 84, 1166-1173.

Quirk, S.M. \& Fortune, J.E. (1986) Plasma concentrations of gonadotrophins, preovulatory follicular development and luteal function associated with bovine follicular fluid-induced delay of oestrus in heifers. J. Reprod. Fert. 76, 609-621.

Quirk, S.M., Hickey, G.J. \& Fortune, J.E. (1986) Growth and regression of ovarian follicles during the follicular phase of the oestrous cycle in heifers undergoing spontaneous and PGF-2 $\alpha$-induced luteolysis. J. Reprod. Fert. 77, 211-219.

Rahe, C.H., Owens, R.E., Fleeger, J.L., Newton, H.J. \& Harms, P.G. (1980) Pattern of plasma luteinizing hormone in the cyclic cow: dependence upon period of the cycle. Endocrinology 107, 498-503.

Richards, J.S. (1980) Maturation of ovarian follicles: actions and interactions of pituitary and ovarian hormones on follicular cell differentiation. Physiol. Rev. 60, 51-89.

Robertson, D.M., Foulds, L.M., Leversha, L., Morgan, F.J., Hearn M.T.W., Burger, H.G., Wettenhall, R.E.H. \& deKretser, D.M. (1985) Isolation of inhibin from bovine follicular fluid. Biochem. Biophys. Res. Commun. 126, 220-226.

Roche, J.F. \& Ireland, J.J. (1981) The differential effect of progesterone on concentrations of luteinizing hormone and follicle-stimulating hormone in heifers. Endocrinology 108, 568-572.

Savio, J.D., Keenan, L., Boland, M.P. \& Roche, J.F. (1988) Pattern of growth of dominant follicles during the oestrous cycle of heifers. J. Reprod. Fert. 83, 663-671.

Schallenberger, E., Schams, D., Bullerman, B. \& Walters, D.L. (1984) Pulsatile secretion of gonadotrophins, ovarian steroids and ovarian oxytocin during prostaglandin-induced regression of the corpus luteum in the cow. J. Reprod. Fert. 71, 493-501.

Schallenberger, E., Schöndorfer, A.M. \& Walters, D.L. (1985) Gonadotrophins and ovarian steroids in cattle I. Pulsatile changes of concentrations in the jugular vein throughout the oestrous cycle. Acta endocr., Copenh. 108, 312-321.

Shemesh, M., Ayalon, N. \& Lindner, H.R. (1972) Oestradiol levels in the peripheral blood of cows during the oestrous cycle. J. Endocr. 55, 73-78. 
Sirois, J. \& Fortune, J.E. (1988) Ovarian follicular dynamics during the estrous cycle in heifers monitored by real-time ultrasonography. Biol. Reprod. 39, 308-317.

Statistical Analysis Systems. (1985) SAS User's Guide: Statistics. SAS Institute, Inc., Cary.

Tsafriri, A. (1988) Local nonsteroidal regulators of ovarian function. In The Physiology of Reproduction, pp. 527-565. Eds E. Knobil \& J. D. Neill. Raven Press, New York.

Turzillo, A.M. \& Fortune, J.E. (1989) Suppression of the secondary FSH surge with bovine follicular fluid (bFF) affects ovarian follicular dynamics in Holstein heifers. J. Reprod. Fert., Abstr. Ser. 3, 35, Abstr. 60.
Wallace, J.M. \& McNeilly, A.S. (1985) Increase in ovulation rate after treatment of ewes with bovine follicular fluid in the luteal phase of the oestrous cycle. $J$. Reprod. Fert. 73, 505-515.

Walters, D.L. \& Schallenberger E. (1984) Pulsatile secretion of gonadotrophins, ovarian steroids and ovarian oxytocin during the periovulatory phase of the oestrous cycle in the cow. J. Reprod. Fert. 71, $503-512$.

Received 13 November 1989 